\title{
Adaptation of constant effort sampling and of removal trapping for the estimation of populations of microscopic organisms in dense substrates $\left(^{*}\right)$
}

\author{
Ilse Walker (**) \\ Maryolanda Trindade Lages ("*)
}

\begin{abstract}
Large numbers of thecamoebae are found in the sand and detritus substrate of small streams in the Amazonian terra firme forest. Their relative population densities can be determined by searching and counting thecae under a dissecting microscope for a standard time interval (constant effort sampling). The total population per sample can be calculated from a gradual linear depletion during successive such counts in a given sample (removal trapping). From a series of such regressions the total number of thecamoebae of any sample can be estimated from a single, first count. The method depends on specific conditions with regard to size of area searched, quantity of substrate per area, density of organisms per substrate and performance of the observers. These conditions are generally valid for similar methodical treatment of any population of small organisms in any type of dense substrate. The linear regression of the depletion effect implies a constant mean probability for any thecamoeba to be found in the specified substrate during the specified time interval by any of the three observers involved in the study, and this despite the uncontrollable subjectivity of visual search in a microscopic field.
\end{abstract}

\section{INTRODUCTION}

The necessity to define a sampling method arose from the aim to characterize populations of thecamoebae, the prevalent protozoan group in the sand and detritus substrate of small Amazonian forest streams. They occur in such quantities that they may actually constitute an important link in the food chains which start with decomposition of submerged leaf litter, and furthermore, they may be suitable indicator organisms for natural water qualities and for pollution. Accurate sampling is impossible because of the inhomogeneity of the substrate, and finding all organisms in a representative sample of soil, sand, detritus and plant debris is impossible as well. As the problems encountered are similar for limnologists, soil biologists, pathologists, and for researchers which work with pests of human food stores and animal feeds, our results with thecamoebae might be of a more general interest.

Inhomogeneity of the biotope to be sampled is a problem which faces almost all ecologists. However, working with macroscopic areas and organisms allows for reasonably objective standarization of the constant sampling effort: a constant number of sweeps with sweep nets may be taken to sample grassland insects (Waloff \& Solomon, 1973); better still, sampling for fixed periods in a fixed number of spots by mechanical devices (electric aspirators in short vegetation, light and suction traps for flying insects etc; Southwood, 1968) can- if all precautions are taken-exclude almost all subjective components. By contrast, if it comes to visual search under the microscope. almost all is uncontrollably subjetive, and the issue would be suitable for a study in "Wahrnehmungspsychology". How long is one giving attention to a given observable spot? How large is this spot and to where is one shifting attention the next instant? When is one deciding to stir up the substrate and when to rotate the petri dish? No matter how the sample is chosen, one is faced witlı the same questions. Simple counting on a regular grid, as is the case in transparent substrates, is not possible.

Instead of focusing attention on the microbehaviour of the observer, one may let several observers search for a given period without

\footnotetext{
(•) - This study was supported by a joint project between CNPq, OEA and SUFRAMA: "Ecologia da Floresta Tropical".

(**) - Instituto Nacional de Pesquisas da Amazônia, Manaus.
} 
giving special instructions with regard to their searching method and see whether results are reproducible within statistically accept ble limits. Furthermore, one can test the sensitivity of the search towards the crucial physical parameters of the sample such as amount of solid substrate per petri dish, density of substrate per area and size of area to be searched. What we are really interested in is the density of organisms per substrate. The result of a search for $10 \mathrm{~min}$, for example. should reflect this density and therefore, should be relatively independent of area and amount of material searched. In other words, the method to estimate relative densities of organisms should be robust with regard to these parameters; provided only that there is excess substrate, one should come up with reproducible results.

By contrast, estimation of absolute population numbers by removal trapping depends on a gradual depletion of the organisms in the sampled area, hence, density of material per area and size of area must be chosen small enough in order to be sensitive towards a reduction of the density of organisms per substrate.

Initial sampling series of the thecamoebae from several localities within the INPA forest reserves produced some rather comforting results. In the following, the methodology is analysed according to the points of view outlined above. The ecological results and list of morphotypes will be published in a later communication. General problems of constant effort sampling and of removal trapping are reviewed by Southwood (1968) and will, where necessary, be mentioned with the results or in the discussion.

\section{MATERIAL AND SAMPLING METHOD}

Some 25 - 35 distinguishable morphotypes of thecamoebae, with their longest diameters ranging from $25 \mu \mathrm{m}$ to $\sim 500 \mu \mathrm{m}$ are found in the bottom substrate of single small forest streams. The thecae are composed of sand grains and detritus particles which are glued together with the cell's own excretion. A wide range of species includes no foreign particles at all, their thecae consist of excretion alone, the structure of which is recognizably species-specific. They live preferably in areas of low current where light detritus particles accumulate over a sandy substrate. In order to characterize density and composition of these populations along an $80-100 \mathrm{~m}$ stretch of a stream, 12 samples were taken at a distance of $6-12$ $\mathrm{m}$ according to the presence of "amoebae biotope". This was the first decision to be taken: whether to sample rigorously at a fixed distance, regardless of the character of the bottom substrate, or to choose special sites where amoebae were known to be found and where the substrate allowed for reasonably standardized sampling; one cannot compare a sample of leaf litter with a sample of fine detritus. Transferring the problem to the macroscopic scale it must be said in all fairness that ecological entomogists, for example, also choose sample areas where the organisms they are interested in are likely to be found. We thus did not sample "the stream" but the sand-detritus biotope of the stream. In order not to disturb the sample area, samples were taken in the up-stream direction.

Wide-mouthed sample bottles of $250 \mathrm{ml}$ capacity with a bottom diameter of $6 \mathrm{~cm}$, were filled carefully with water at the sampling spot, then lowered horizontally onto the substrate. With the free hand material was scooped into the bottle in such a way that, after settling, the substrate layer in the bottle was $5.0 \pm 1.0$ $\mathrm{mm}$ deep. With a bit of routine, the quantity to be taken can easily be standardized within these limits. In the laboratory the samples were left to settle for a minimum of 4 hours. Then all but $120 \pm 2 \mathrm{ml}$ of the water carefully decanted, the rest rigorously stirred and $35 \pm 1 \mathrm{ml}$ of the agitated suspension was transferred, via a calibrated flask, into a petri dish of $8.3 \mathrm{~cm}$ diameter. This results in about $2.3 \pm 0.5 \mathrm{ml}$ settled detritus spread out over the petri dish's surface of $54 \mathrm{~cm}^{2}$. The petri dish was then placed under the dissecting microscope and the material allowed to settle for several minutes. (Fortunately, reproduction is practically absent in such freshly taken 
samples. In aged, small ecosystems, one or the other species may suddenly break out in a boom, but this was only observed after several weeks of laboratory existence (Walker. 1978). As we are also interested in the biology of this hitherto undescribed fauna, we worked with unfixed material throughout). The observer was then allowed to search and remove thecamoebae with a fine pipette for 10 minutes without specified instructions on the details of this search. The removed thecae may or may not contain a live cell. This is a difficulty in the estimation of a population we could so far not resolve because at present we have no facility to inspect the material at the sample site, and we do not know what dies during a transport over $80 \mathrm{~km}$ on unpaved roads. However, in this study we are concerned only with methodological aspects of sampling and counting. The material is sorted and counted after the removal during 10 minutes; in this paper only total numbers per $10 \mathrm{~min}$ search, irrespective of morphotypes, are considered. Five persons were involved in sampling and four in searching and counting, namely one experienced and three initially unexperienced observers. Zeiss and Wild M 7A stereo microscopes were used at magnifications of $30 x$ to $40 \mathrm{x}$.

Modifications of this standard method for experimental reasons will be mentioned with the respective results.

\section{ANALySIS OF METHOD}

ESTIMATION OF RELATIVE POPULATION DENSITY

\section{First Results}

The first two series of 12 samples each compared a black water stream with a clear water stream. The results were sufficiently representative, so that we decided to continue with the formerly described standard sampling. Black water substrate contained $41.8 \pm 14.3$ amoebae per $10 \mathrm{~min}$ sample, clear water substrate only $17.5 \pm 4.0$ (t-test, $\mathrm{P}<0.001$ ).

\section{Personal bias}

The above samples were all taken and counted by the experienced observer. Intro- ducing 3 assistants to the method necessitated a careful comparison of the performance before results of diverse persons could be included into the evaluation of data.

Fig. 1 shows that beginners find considerably less amoebae per sample, both in high density and low density series, but that eventually comparable results are obtained.

\section{Quantity of substrate searched}

Instead of $35 \mathrm{ml}$ stirred suspension as in the standard method, 40 and $20 \mathrm{ml}$ were given into the petri dishes. The detritus-sand mixture, when settled over night, is $2.5 \mathrm{ml}$ in the first case and $1.25 \mathrm{ml}$ in the second. Naturally, half the substrate results in a thinner layer on the petridish. This could have either of two opposing effects: thecae might be more visible and the search facilitated, or local depletion would prolong the search per theca. Two consecutive samples of $10 \mathrm{~min}$ were removed from each petridish in order to discover a
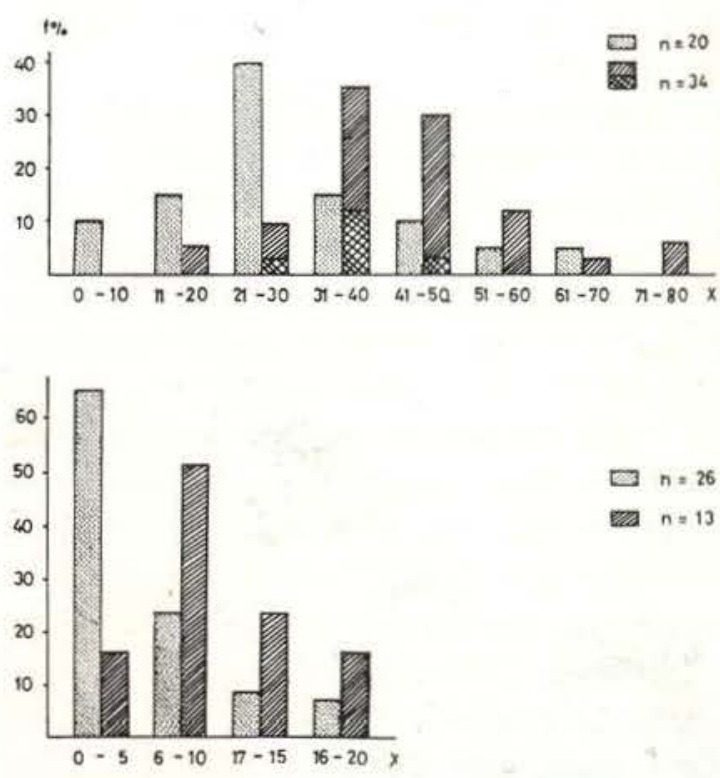

Fig. 1 - Histograms of performance of unexperienced (dotted) and experienced (hatched; cross - hatched: fcrmerly inexperienced) observers. $x=$ class of density of thecamoebae as determined by a $10 \mathrm{~min}$. count; $f=$ frequency of results within respective $x$-class; $n=$ number of samples $(=100 \%)$. A: samples from a stream with high density of amoebae; $B$ : samples from a low density stream. 
possible depletion effect. Two experienced observers were involved in counting, both doing all 4 types of sampling $(20 \mathrm{ml}, 40 \mathrm{ml}$, first and second counts). Table 1 shows that within the quantities of substrate searched the method is completely robust, i. e. the result is not influenced by the amount of substrate on the petridish.

TABLE 1 - Robustness of method with regard to quantity of material searched. $\mathbf{n}=$ number of replicates; $\bar{x}_{1}, \bar{x}_{2}=$ mean number of amoebae removed during two consecutive counts of $10 \mathrm{~min}$ in the same sample dish.

\begin{tabular}{l|c|c|c|c}
\hline Sampling & $y_{1} \pm \mathrm{S}$ & $\mathrm{y}_{2} \pm \mathrm{S}$ & $\mathrm{n}_{1}=\mathrm{n}_{2}$ & $\mathrm{t}$-test \\
\hline $40 \mathrm{ml} /$ dish & $\begin{array}{c}31.75 \pm 5.26 \\
\mathrm{P} \sim 0.85\end{array}$ & $31.50 \pm 6.44$ & 8 & $\mathrm{P} \sim 080$ \\
$20 \mathrm{ml} /$ dish & $30.33 \pm 6.25$ & $30.00 \pm 4.10$ & 6 & $\mathrm{P} \sim 0.90$ \\
\hline
\end{tabular}

\section{Area searched}

Thirty-five $\mathrm{ml}$ of substrate suspension was given on all petri dishes, but apart from controls in which searching was allowed over the whole (1/1) area, searching was restricted to sectors of $1 / 2,1 / 4$ and $1 / 8$. Each of these sectors was counted on a different dish. The material for a series of all 4 areal sizes came from pooled samples, so that differences of results would reflect method rather than sample variation. Three experienced observers were involved in the counting; two consecutive samples of $10 \mathrm{~min}$. were removed from each sector. Table 2 confirms the robustness of the method with regard to first and second count in the whole dish, although this population is considerably less dense than the one in table 1; furthermore results are similar whether one searches over the whole, or over $1 / 2$ petri dish only in a single first $10 \mathrm{~min}$ sample. However, significant depletion appears in the second count if only half of the area is searched. Less amoebae are found in $1 / 4$ and $1 / 8$ dishes, and the depletion effects are accentuated; however, a significant reduction in first counts occurs only when the area is reduced to $1 / 8$. Thus, our initially adopted, intuitive method is highly robust not only with regard to the quantity of substrate, but also with regard to area searched. It makes no difference, whether observers shift the dish somewhat more or less often, they would still come up with largely the same results. Differences in results reflect above all different densities of amoebae per substrate, and this is the population parameter one wants to characterize.

\section{Searching time and removing time}

Lastly, a problem needs to be mentionend which, so far, did not present itself, but will have to be borne in mind whenever one is sampling by searching and removal. For the constant sampling effort we fix a standard sampling period $\Delta T$. Searching and removing organisms is a time-consuming process; an experienced and efficient observer will invest a minimum time interval $\Delta t$ per organism to find and remove it. The maximum number of animals he can remove per sample is thus $\frac{\Delta T}{\Delta t}$

, i. e. it is defined by the physical parameters of the sampling method and not by the density of organisms present. Population densities above this critical methodological density cannot be distinguished anynore; in short: if the observer sees more organisms than he has time to remove the method delivers no meaningful results. Seeing one organism whilst one is engaged in removing another are two activities which can take place simultaneouly, therefore, the minimal removal time is the limiting factor which determines the critical upper density for the method. The method depends on the difficulty to see organisms in dense substrate, $\mathbf{i}$. e. on the time interval between seeing sequentially appearing organisms. The observer "searches" if the mean time interval between seeing two consecutive organisms is larger than the mean time interval needed to remove one. In actual fact, the method depends on the quantity of substrate per organism, if there is not enough substrate, it breaks down. Should this happen, one could remedy the case by adding neutrai, dense substrate to all samples of an investigation 
(for instance pure sand in the case of thecamoebae). This method would be equivalent to dilution of transparent medium as serum or nutrient solution when counting blood cells or bacteria for example; counting, too, is a physical process which depends on the possibility to put a time interval between distiguishing two objects on a field (this method breaks down when there are more organisms per area than one can discern). There is one interesting point with regard to inexperienced beginners: if they were limited by difficulties in removing the organisms, the histogram of the results (Fig. 1) would be skewed towards maximum numbers counted per sample. This is, by the way, also true in the case of the experienced observer when he hits the critical density; for the unexperienced person, the critical density would merely be at lower values. If the beginner were limited by finding the organisms, then the histogram would accentuate the normal asymmetry of the Poisson distribution towards low numbers found per sample. This was, in fact, what happened in our case.

\section{ESTIMATION OF ABSOLUTE POPULATION NUMBERS}

\section{Response of depletion to area searched}

The course of depletion for various sizes of sizes of areas searched is shown in Fig. 2 (these are different samples from Table 2). The number of amoebae found in each count is plotted against the total previously removed. Naturally, the method of plotting the data results in regression as the number found decreases during successive counts while the total removed increases. There is, however, no compelling reason why this should be a straight line. The mathematical theory of this method was worked out by De Lury (1974) and Zippin (1956) who departed from the assumption of constant probability to find the organisms. Yet, in the microbiological method these probabilities are subjective and may vary in the course of successive counts (trying harder or tiring for instance). Thus, we depart from the empirical data and use the caculation of regression - not to prove regression - but to fit the best straight line and to estimate its "goodness" (correlation coefficients $r$ in Table 5 and Fig. 2; Menhinick 1963, Southwood 1968). It appears that the fit is relatively good, and should further counts decrease along the line, the intersect with the abcissa should give an estimate of the total amoebae present in the area. Table 3 and Fig. 2 give evidence that for the whole area the method leads to massive underestimation. Assuming that several replicate counts in the smallest area $(1 / 8=6.76$ $\mathrm{cm}^{2}$ ) give the most realistic results, the whole dish should contain roughly 8 times that number.

Yet, the $1 / 2$ dish with similar density as the whole shows the same total estimate as the whole dish. The reason for this underestimate is probably that the observer does not explore the whole area and depletion may thus be local. An analysis of depletion for 15 samples of whole (1/1) dishes searched certainly suggests that decrease between counts is rather erratic (Tab. 4), what would be expected in the case of irregular search over the surface of the petri dish. The relative small decreases between first and third counts reflect the robusteness of the method with regard to area and substrate.

TABLE 2 - Effect of the size of area searched; the whole (1/1) dish is $54 \mathrm{~cm}^{2} . y_{1}, y_{2}=$ mean number of amoeb 20 of $n$ replicates removed in 2 consecutive counts of $10 \mathrm{~min}$.

\begin{tabular}{l|c|r|r|rr}
\hline \multicolumn{1}{c|}{ S a mpling } & $y_{1} \pm \mathrm{S}$ & $\mathrm{y}_{2} \pm \mathrm{S}$ & $\mathrm{n}_{1}=\mathrm{n}_{2}$ & $\mathrm{y}_{2} / \mathrm{y}_{1}$ & $\mathrm{t}-\mathrm{test}$ \\
\hline $1 / 1$ (whole) dish & $21.50 \pm 5.45$ & $19.75 \pm 4.57$ & 4 & 0.92 & $\mathrm{P} \sim 0.25$ \\
$1 / 2$ dish & $19.33 \pm 3.83$ & $14.67 \pm 2.16$ & 6 & 0.76 & $\mathrm{P}<0.025$ \\
$1 / 4$ dish & $18.83 \pm 5.85$ & $11.83 \pm 4.62$ & 6 & 0.63 & $\mathrm{P}<0.005$ \\
$1 / 8$ dish & $15.85 \pm 4.62$ & $7.67 \pm 2.06$ & 12 & 0.49 & $\mathrm{P}<0.001$ \\
\hline
\end{tabular}




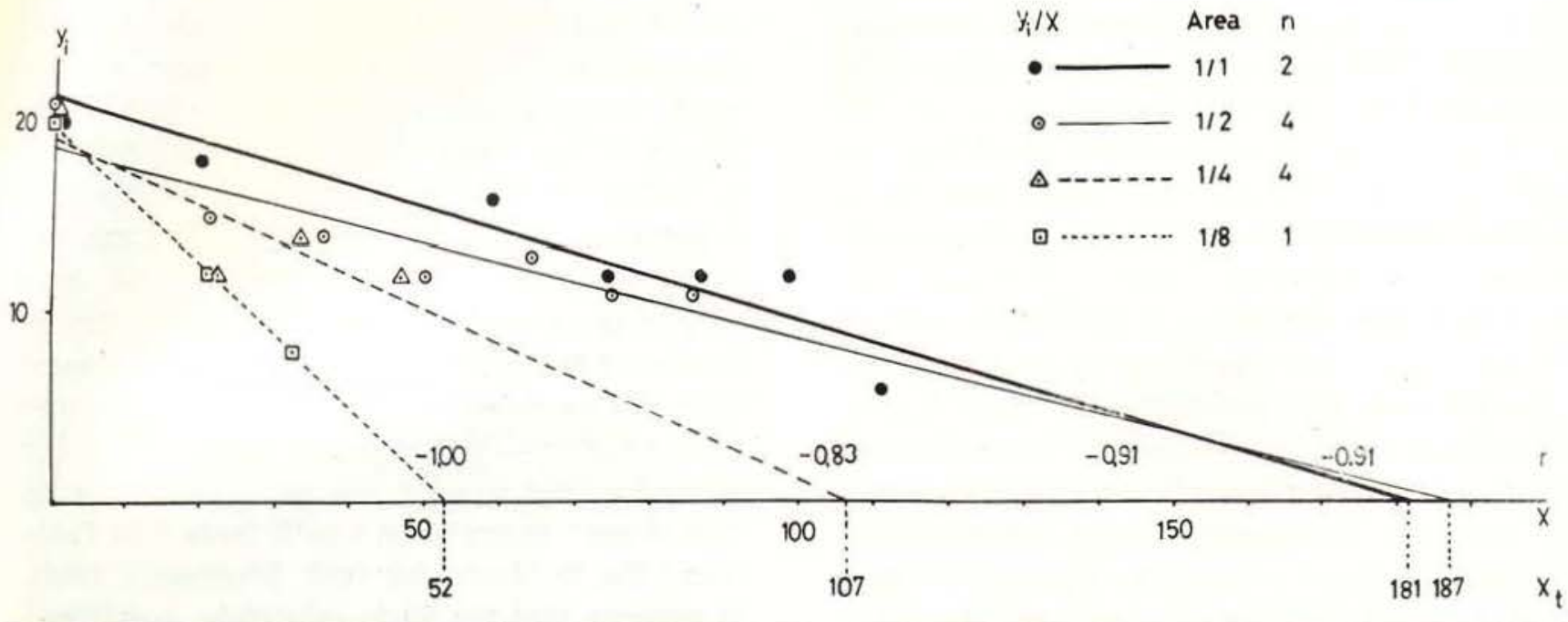

Fig. 2 - Fit of linear regression to sucessive removal co unts $\left(y_{i}\right)$ in samples with various areas $(1 / 1$ dish $=54$ $\mathrm{cm}^{2}$ ). $\mathrm{x}=\sum_{\mathrm{i}=1}^{i-1} \mathrm{y}_{\mathrm{i}}=$ total amoebae previously removed; $\mathrm{x}_{\mathrm{t}}=$ total number of amoebae as calculated by regression. Each point represents the mean in $n$ samples of comparable initial densities $y_{1}$.

The relations between the counts in $1 / 2$, $1 / 4$ and $1 / 8$ dish are more consistent with the simple expectation that doubling area and substrate results in double population size.

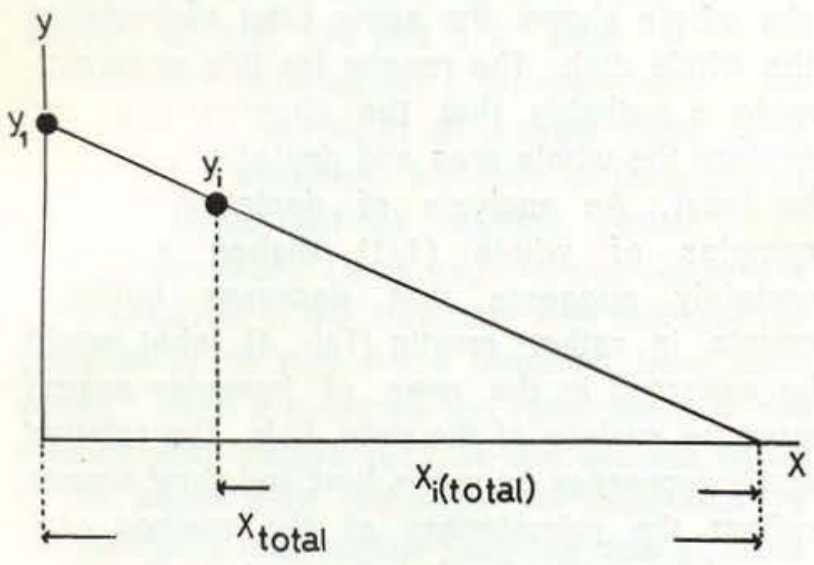

Flg. 3 - Ideal linear regression in removal counting and constant probability $(p)$ to find an organism in a set of samples. $y_{1}=$ first removal cout in a sample; $y_{i}=i-$ th count in this sample or the first count in a different sample with a lower density of organIsms. $\mathrm{x}=$ total organisms removed by previous counts: $x_{i(\text { total })}=$ total organisms per sample if $y_{1}$ is the first count; $x_{i(t o t a l)}=$ total organisms per sample if $y_{i}$ is the first count.

$p=\frac{y_{1}}{x_{\text {total }}}=\frac{y_{i}}{x_{i(\text { tota })}}=$ constant
From this follows, that for absolute, total population estimates smaller areas are recommended, in our case dishes of $10-20 \mathrm{~cm}^{2}$ with $0.5-1.0 \mathrm{ml}$ settled substrate, covered with sufficient water to facilitate the search (p. 2); that is, we have to give up robustness of area and quantity of substrate which are desirable for estimates of relative population density.

TABLE 3 - Effect of area searched on the estimated total number amoebae per sample $\left(x_{\text {total }}\right)$ as calcu-

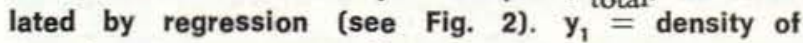
amoebae per sample as determined by the first $10 \mathrm{~min}$ count. $x_{\text {exp }}=$ total per sample expected if $x_{\text {total }}$ of the $1 / 8$ area is assumed to represent the most realistic number $\left(" x_{\text {total }}=x_{\text {exp }}\right)$.

\begin{tabular}{l|c|r|r|r}
\hline Area & $\begin{array}{c}y_{1} \\
\text { (counted) }\end{array}$ & $\begin{array}{c}x_{\text {total }} \\
\text { (calculated) }\end{array}$ & $x_{\text {exp }}$ & $x_{\text {total }}$ \\
\hline \multirow{2}{*}{$1 / 1$} & 17 & 164.27 & 292.48 & $x_{\text {exp }}$ \\
& 20 & 181.17 & 418.53 & 0.56 \\
$1 / 2$ & 21 & 187.60 & 209.26 & 0.90 \\
$1 / 4$ & 21 & 106.94 & 104.63 & 1.02 \\
$1 / 8$ & 20 & 52.32 & $* 52.32$ & 1.00 \\
& 17 & 36.58 & $* 36.53$ & 1.00 \\
\hline
\end{tabular}




\section{Estimation of total numbers from single, first counts}

In our ecological study we want to compare density and diversity of thecamoebae from different streams and hence, we rely on the robustness of the method. Still, one would like to have an approximate idea on the order of magnitude of absolute numbers. It is reasonable to assume that in samples of comparable size and type of substrate, successive depletion results in similar regression lines in samples with similar initial densities as reflected in the first count. The total estimate would then be a function of this initial density and perhaps of a behavioural bias, as initial density may influence the performance of the observer. Without such bias we should get a straight line if we plot the estimated totals against the first counts. This follows by necessity from the fact that a straight line is a reasonable fit for the data of depletion in individual samples. On such a regression line any one of the various $y_{i}$ could be the first count in a sample with a respectively lower density of organisms, and the section $x_{i}$ (total) of the absissa then represents the total population of the dish at the beginning of this first count $y_{i}$ (Fig. 3). $y_{i} / x_{i}$ (total) $=$ constant, this means that in any one count of 10 minutes, whether it is the first count in a sample of any density, or the $\mathrm{i}$-th count within a single sample we always remove the same proportion of the population present in the dish. Hence, if we plot our first counts of various samples against the calculated totals we should get a straight line, from which the expected total population can be read off, if we determined the first count only. Fig. 4, representing the data of Table 5, shows, that a straight line is indeed a reasonable fit

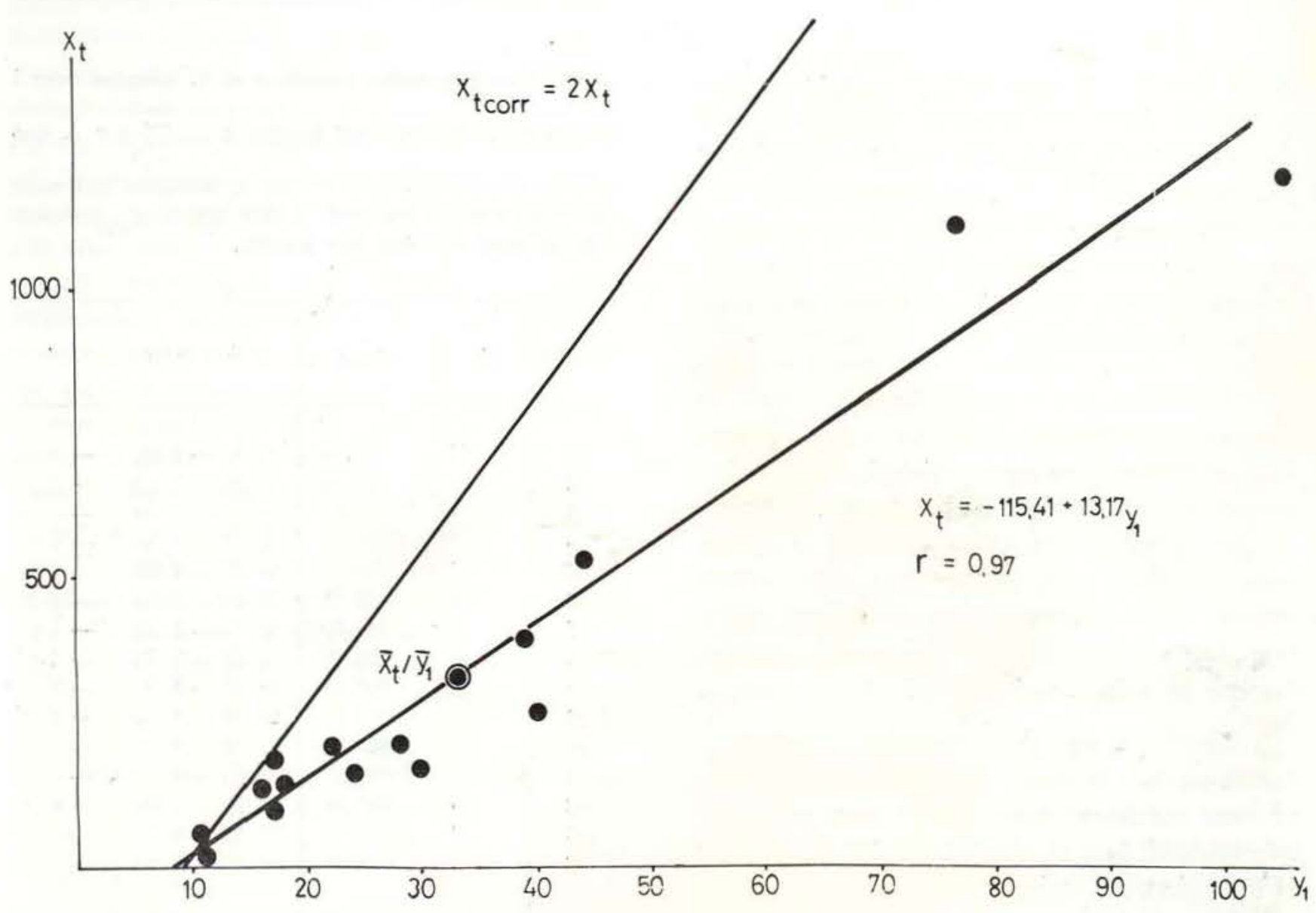

Fig. 4 - Estimation of expected total number amoebae $\left(x_{t}\right)$ in a sample from a first 10 min. count $\left(y_{1}\right)$ by way of a regression line between the $x_{t}$ and $y_{1}$ points from the 15 samples in Table $5 . x_{t}$ corr.: see explanation $p$. 
TABLE 4 - Pattern of differences between sequential removal counts $y_{i}$ within 15 samples as a function of $i$ and of initial density $y_{1}(=$ first 10 min count).

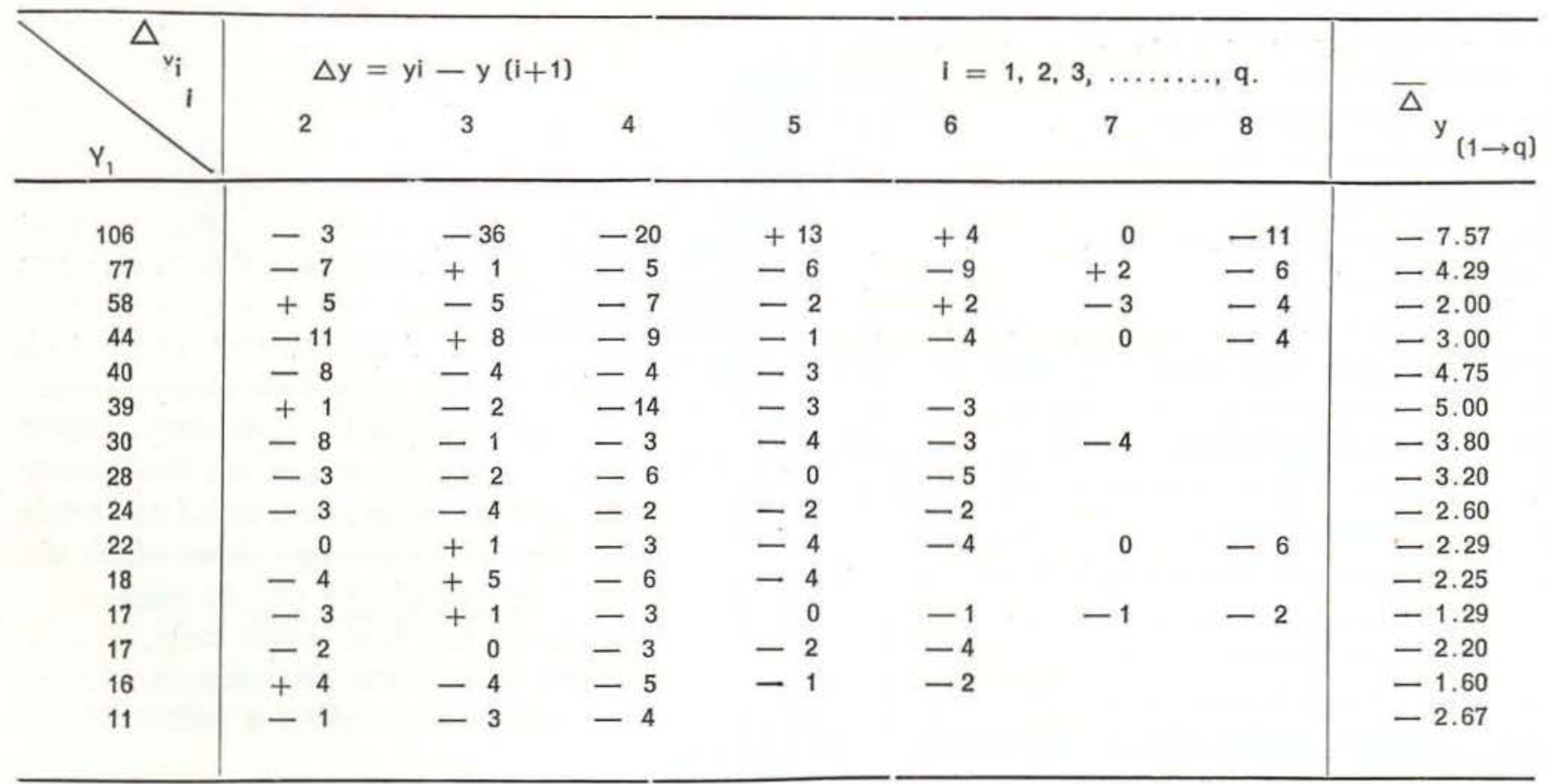

$(r=0.97)$. Consequently, searching performance does not seem to be significantly influenced by initial density, and Zippin's (1956) assumption, that the mean probability to find any one organism is constant for a specified population and searching time, is justified, even in the case of highly subjective searching under the microscope.

We may thus regard the line, fitted by regression to the $y_{1} /$ total points, as a standardized calibration line from which to read off the expected total number of thecamoebae for our $10 \mathrm{~min}$ samples. As the line refers to counts over the whole area of the petri dish. which results in an under-estimate of roughly $100 \%$ (see Table 3 and Fig. 2), we have to correct the line by a factor of two (Fig. 4).

Clearly, since this empirical proceedure allows us only to guess the order of magnitude of total numbers, accuracy of results cannot be expected. But, in view of the inhomogeneity of the substrate and of the enormous variation of the amoebae biotop along a stream, any further elaboration of method and theory would seem a lost effort.
TABLE 5 - Regression equations of 15 samples from $i$ sucessive $10 \mathrm{~min}$ removal counts; $z \simeq \sum_{i=1}^{i-1} y_{i} ; \mathbf{r}=$ correlation coefficient; $y_{1}=$ density of amoebae in sample as determined by tre first 10 min count; $x_{\text {total }}=\mathrm{cal}$ culated total amoebae per sample.

\begin{tabular}{|c|c|c|c|c|}
\hline Sample & $y_{1}$ & $x_{\text {total }}$ & $y_{i}=a+b z$ & $r$ \\
\hline 1 & 11 & 17.14 & $11.31-0.66 z$ & -0.99 \\
\hline 2 & 11 & 54.18 & $11.92-0.22 z$ & -0.94 \\
\hline 3 & 16 & 136.97 & $19.15-0.14 z$ & -0.87 \\
\hline 4 & 17 & 102.61 & $18.47-0.18 z$ & -0.93 \\
\hline 5 & 17 & 185.22 & $16.67-0.09 z$ & -0.96 \\
\hline 6 & 18 & 137.75 & $18.53-0.12 z$ & -0.75 \\
\hline 7 & 22 & 210.92 & $25.31-0.12 z$ & -0.91 \\
\hline 8 & 24 & 160.47 & $24.07-0.15 z$ & -1.00 \\
\hline 9 & 28 & 206.00 & $28.84-0.14 z$ & -0.98 \\
\hline 10 & 30 & 167.47 & $28.74-0.17 z$ & -0.97 \\
\hline 11 & 39 & 394.18 & $43.36-0.11 z$ & -0.88 \\
\hline 12 & 40 & 260.87 & $39.13-0.15 z$ & -0.99 \\
\hline 13 & 44 & 527.88 & $42.23-0.08 z$ & -0.91 \\
\hline 14 & 77 & 1112.14 & $77.85-0.07 z$ & -0.97 \\
\hline 15 & 106 & 1182.50 & $94.60-0.08 z$ & -0.77 \\
\hline Mean & 33.33 & 323.75 & \multicolumn{2}{|c|}{$r=-0.90 \pm 0.08$} \\
\hline
\end{tabular}


Referring to the mean number of amoebae found in two different streams (18 and 42 , see p...), we would expect 230 and 930 per dish respectively; this gives a range of 82 - 404 thecamoebae $/ \mathrm{ml}$ settled detritus (p. ..). Even assuming that only a fraction of these is alive at any one time, it means that stream detritus in Amazonian terra firme forest is intensively exploited by thecamoebae.

\section{CONCLUSIONS}

All data support the conclusion that populations of small organisms in dense substrates can be assessed with confidence by the methods of constant effort sampling and removal trapping which avoid the tedium of having to find all organisms in a sample. This is true provided certain precautions are taken. First, the histogram of frequencies of the densities of organisms in a series of samples (called simply "performance" in the following) must show a Poisson distribution; asymmetry towards relatively too many samples with highest densities indicates that the densities are too high to be assessed by the method. and the case must be remedied by diluting the samples with suitable substrate (finest saw dust and desert sand in our case for example). Second, observers must be trained until their performance is constant within statistically tolerable limits. This situation is different from the one with a beginner counting erythrocytes in clear serum for example. A careful beginner delivers the same results as the experienced observer, he merely needs more time to count all cells in a given number of fields. In the constant effort sampling method the observation time is limited and the unexperienced observer produces different results. Third, if several investigators contribute to a joint study, they can be trusted to sample different areas only if their performance is similar, otherwise they must contribute constant fractions of data to each series (for instance each of two observers counts half of the samples of each area).

Given the enormous possibility for personal bias in microbehaviour when searching through a microscope, constant probability to find an organism as implied by straight line regression is surprising. Three experienced observers produced the data in Table 5 and Fig. 4. This may mean that visual search of known objects in known substrates relies on elementary physico-physiological processes which vary little between individuals. This is a comforting thought, particularly for ecologists. No conceivable machine could pick out dozens of different types of thecae composed of sand and detritus from an environment of sand and detritus, but man can. It may be good to be reminded at times that precise machines are the product of man and not vice-versa, and that trustworthyness of data relies on the critical mind of the observer, whether he uses his own sense organs or mechanical substitutes.

\section{ACKNOWLEDGEMENTS}

The authors are thanking Dr. R.M. Williams and Sr. Miguel Petrere Júnior for their assistance in clarifying theoretical aspects of the depletion process which, however, are not shown in extenso in this paper, but led to the final version of the script (straight line regression and constant probability: $\mathrm{Dr}$. R. M. Williams; other possible depletion curves: Sr. $\mathrm{M}$. Petrere Jr.); they acknowledge furthermore the assistance of Sr. Luiz Fernandez Aivez and Sr. Joaquim Rodrigues de Melo in counting thecamoebae and are grateful to Dr. M. Goulding for critically reading the final script

\section{RESUMO}

Altas densidades de tecamebas (Rhizopoda, Protozoa) foram encontradas no substrato misto de detritos e areia nos igarapés de floresta primária na região de Manaus (Reservas florestais Ducke e km 60 BR-174). Foi desenvolvido o método para determinar as densidades relativas de amebas entre vários igarapés e a densidade absoluta ( $\mathrm{n} \% / \mathrm{ml}$ substrato). Amostras deste substrato foram postas sob o estéreo-microscópio e procurava-se amebas durante $10 \mathrm{~min}$. em cada amostra. As tecas encontradas eram tiradas da placa de petri e contadas. O método depende do fato de procura: precisa-se mais tempo por organismo na medida em que diminui a den- 
sidade. Se não há procura, o que quer dizer, se são vistos mais organismos de que há tempo de tirar da placa em $10 \mathrm{~min}$., o método somente pode ser aplicacic se todas as amostras são diluídas com substrato semelhante sem organismos. O método pode ser aplicado em geral para amostragens de micro-organismos em qualquer substrato denso desde que a quantidade de material por área e a área pesquisada (tamanho da placa ou área da placa) sejam adequados, e que o observador familiarize-se com o material e o método até serem obtidos resultados reproduziveis.

O método para determinar densidades relativas É robusto: obtém-se os mesmos resultados com 20 e $40 \mathrm{ml}$ de suspensão de material por placa, mesmo se a procura estende-se sobre a área total ou apenas sobre a metade de placa. Assim, dentre limites metodológicos bastante amplos, os resultados refletem a densidade de amebas por substrato; portanto, a amostragem no igarapé não precisa ser feito com precisão volumétrica, o que seria impossivel em visto do materıal ser heterogêneo (areia e detritos).

A determinação da densidade absoluta depende da diminuição do número de amebas durante sucessivas contagens de $10 \mathrm{~min}$. na mesma amostra. O número de amebas tiradas por $10 \mathrm{~min}$. em relação ao número total já retirados segue uma regressão linear. Isto significa que, apesar da subjetividade individual da procura sob um microscópio, a probabilidade média de encontrar uma ameba em qualquer amostra por 3 observadores já bem treinados é constante. Desta regressão calcula-se o número total de amebas por placa. Uma série de tais regressões de amostras com diversas densidades, conduz, com precisão matemática (e em realidade), a uma regressão linear entre as primeiras contagens e os totais por placa. Portanto, esta linha permite estimar o número total de organismos por amostra $(=$ por placa $)$ desde que seja conhecido o número de uma única contagem de $10 \mathrm{~min}$. Resultados realísticos obtém-se somente se a robustez a respeito da quantidade e da área pesquisada é sacrificada: é preciso amostras suficientemente pequenas para serem imediatamente sensíveis à diminuição de organismos durante o processo.
A densidade média, absoluta, encontrada em vários igarapés, varia entre 82 e 402 tecamebas por $1 \mathrm{ml}$ de substrato sedimentado em uma suspensão aquática. Mesmo que seja uma fração somente viva por tempo (e sempre encontram-se amebas vivas), estes números indicam que as tecamebas săo um fator importante na rede alimentar e de decomposição nos igarapés da floresta amazônica.

\section{LITERATURE}

DELURY, D.B.

1947 - On the estimation of biological populations. Biometrics, 3 : 145-167.

Menhinick, E.F.

1963 - Estimation of insect population density in herbaceous vegetation with emphasis on removal sweeping. Ecology, $44: 617-621$.

SOUTHWOOD, T.R.E.

1968 - Ecological methods. Methuen \& Co Ltd. London, $391 \mathrm{pp}$.

WALKER, I.

1978 - Rede de alimentação de invertebrados das águas pretas do sistema rio Negro. 1. Observações sobre a predação de uma ameba do tipo Amoeba discoides. Acta Ama. zonica, $8: 423-438$.

WALOFF, N. \& SOLOMON, M.G.

1973 - Leafhoppers (Auchenorrhyncha: Homoptera) of acid grass land. J. appl. Ecol., 10: 189-212.

ZIPPIN, C.

1956 - An evaluation of the removal method of estimating animal populations. Biometrics, 12 : 163-189.

(Aceito para publicação em 22/11/79) 